\title{
Naar een informatiesysteem onderwijs-arbeidsmarkt. Onderzoekprogramma 1988/1989
}

Citation for published version (APA):

Researchcentrum voor Onderwijs en Arbeidsmarkt, ROA. (1988). Naar een informatiesysteem onderwijsarbeidsmarkt. Onderzoekprogramma 1988/1989. Researchcentrum voor Onderwijs en Arbeidsmarkt, Faculteit der Economische Wetenschappen. ROA Reports No. 001

https://doi.org/10.26481/umarep.1988001

Document status and date:

Published: 01/01/1988

DOI:

10.26481/umarep.1988001

Document Version:

Publisher's PDF, also known as Version of record

\section{Please check the document version of this publication:}

- A submitted manuscript is the version of the article upon submission and before peer-review. There can be important differences between the submitted version and the official published version of record.

People interested in the research are advised to contact the author for the final version of the publication, or visit the DOI to the publisher's website.

- The final author version and the galley proof are versions of the publication after peer review.

- The final published version features the final layout of the paper including the volume, issue and page numbers.

Link to publication

\footnotetext{
General rights rights.

- You may freely distribute the URL identifying the publication in the public portal. please follow below link for the End User Agreement:

www.umlib.nl/taverne-license

Take down policy

If you believe that this document breaches copyright please contact us at:

repository@maastrichtuniversity.nl

providing details and we will investigate your claim.
}

Copyright and moral rights for the publications made accessible in the public portal are retained by the authors and/or other copyright owners and it is a condition of accessing publications that users recognise and abide by the legal requirements associated with these

- Users may download and print one copy of any publication from the public portal for the purpose of private study or research.

- You may not further distribute the material or use it for any profit-making activity or commercial gain

If the publication is distributed under the terms of Article $25 \mathrm{fa}$ of the Dutch Copyright Act, indicated by the "Taverne" license above, 


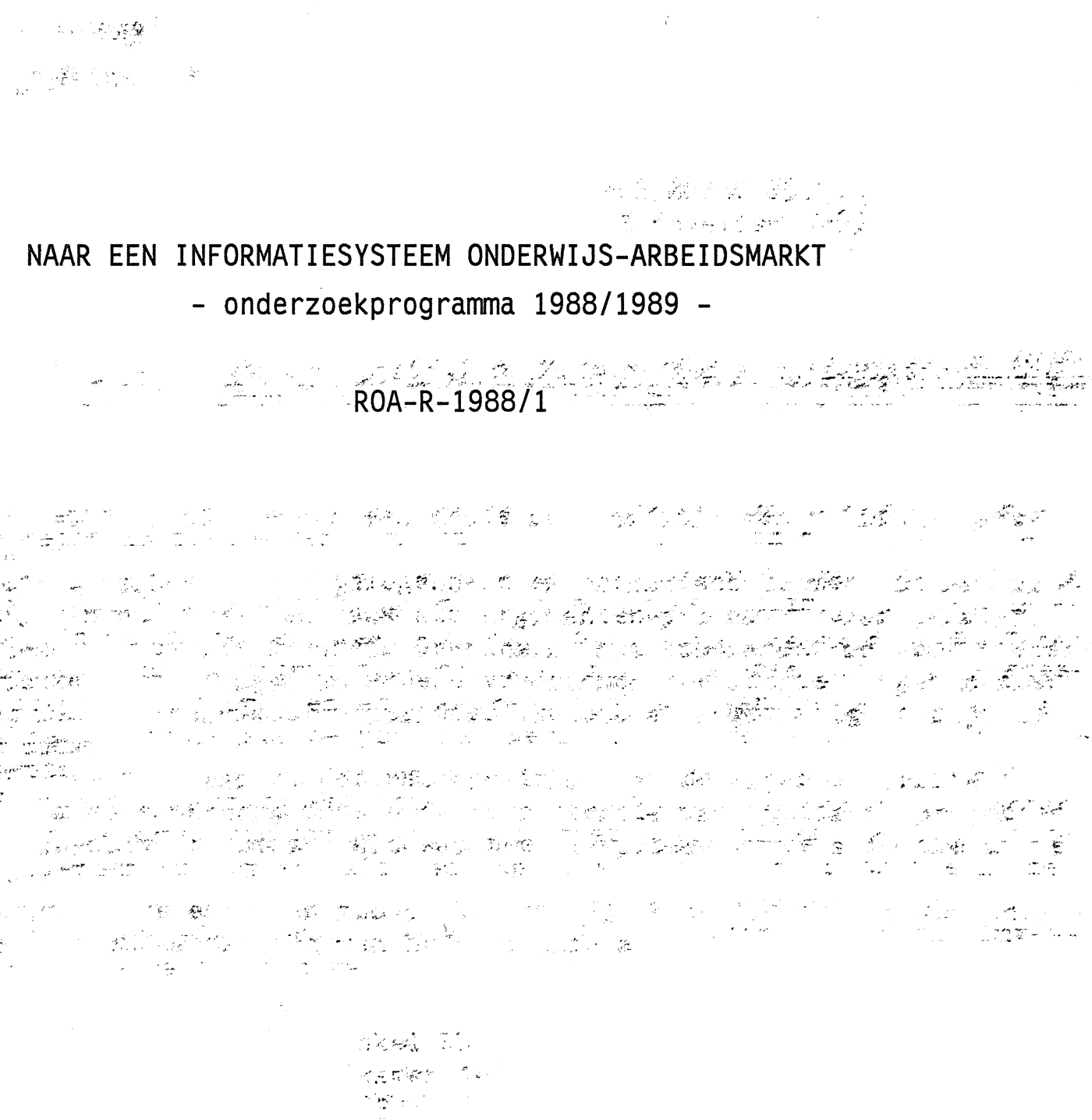

RESEARCHCENTRUM VOOR ONDERWIJS EN ARBEIDSMARKT

Faculteit der Economische Wetenschappen

Rijksuniversiteit Limburg

Maastricht, mei 1988 
bladzijde

Voorwoord

1. Inleiding 3

2. De positie van het ROA 7

3. Het informatiesysteem onderwijs-arbeidsmarkt 10

4. Het onderzoekprogramma 13

4.1. Inleiding 13

4.2. Voortgang van het programma $1987 / 1988$

4.3. Het programma 1988/1989 17

Bijlage 1: Publicaties/Publications ROA 22

Bijlage 2: Personele samenstelling ROA 24

Bijlage 3: Samenstelling begeleidingscommissie van

de meerjarige onderzoeksopdracht van het

Ministerie van Onderwijs en Wetenschappen 
De start van het Researchcentrum voor Onderwijs en Arbeidsmarkt (ROA) in de zomer van 1986 werd mogelijk gemaakt door een meerjarige onderzoeksopdracht van het Ministerie van Onderwijs en Wetenschappen ${ }^{1}$. Deze opdracht houdt in het ontwikkelen van een informatiesysteem waarmee de (toekomstige) ontwikkelingen op de arbeidsmarkt kunnen worden weergegeven en waarin de daarvan afgeleide eisen voor het onderwijs tot uitdrukking kunnen worden gebracht. Het te ontwikkelen systeem zou bruikbaar moeten zijn voor de studie- en beroepskeuzevoorlichting in het voortgezet- en het hoger onderwijs.

Voor de uitvoering van bovengenoemde opdracht is een tweejaarlijks programma van activiteiten ontwikkeld dat jaarlijks wordt aangevuld en bijgesteld. Het eerste programma had betrekking op de periode 1987/$1988^{2}$. Het voorliggende programma is de vernieuwde versie voor de periode $1988 / 1989$.

Behalve de genoemde meerjarige onderzoeksopdracht van het Ministerie van Onderwijs en Wetenschappen, zijn door het ROA inmiddels meer onderzoeksopdrachten verworven. Met name moet hier worden genoemd de bijdrage van het ROA aan de arbeidsmarktmodule van het geautomatiseerde school- en beroepskeuzesysteem I-SEE. Voor een overzicht van de mede op basis van de verkregen onderzoeksopdrachten samengestelde publicaties kan worden verwezen naar bijlage 1 bij dit rapport. De nog lopende projecten buiten de meerjarige onderzoeksopdracht van het Ministerie van Onderwijs en Wetenschappen zijn opgenomen onder het Bgedeelte van het onderzoekprogramma 1988/1989 (zie par. 4.3.).

In het vorige onderzoekprogramma was een overzicht opgenomen van het lopende onderzoek bij de economische faculteit van de Rijksuniversi-

1Zie over de voorgeschiedenis van het ROA: Het Researchcentrum voor Onderwijs en Arbeidsmarkt, ROA-R-1986/1, Maastricht.

${ }^{2}$ Naar een informatiesysteem onderwijs-arbeidsmarkt, onderzoekprogramma 1987/1988, ROA-R-1987/2, Maastricht. 
teit Limburg, voorzover dat onderzoek raakvlakken vertoonde met de ontwikkeling van het informatiesysteem onderwijs-arbeidsmarkt door het ROA. Dit overzicht is in het nieuwe onderzoekprogramma weggelaten. Informatie over deze projecten is te vinden in het jaarverslag van de economische faculteit.

$\mathrm{Na}$ het verschijnen van het vorige onderzoekprogramma is het aantal medewerkers dat aan het ROA is verbonden, toegenomen van acht naar twalf medewerkers. Ter informatie is de huidige personele samenstelling van het ROA weergegeven in bijlage 2 bij dit rapport.

In bijlage 3 wordt een overzicht gegeven van de samenstelling van de begeleidingscommissie van de onderzoeksopdracht van het Ministerie van Onderwijs en Wetenschappen voor de ontwikkeling van het informatiesysteem onderwijs-arbeidsmarkt.

Prof. dr. J.A.M. Heijke, directeur. 


\section{INLEIDING}

In 1986 is door het Ministerie van Onderwijs en Wetenschappen een meerjarige opdracht verstrekt voor het ontwikkelen van een informatiesysteem onderwijs-arbeidsmarkt. Dit systeem zou de toekomstige ontwikkelingen op de arbeidsmarkt moeten kunnen weergeven en de hieruit af te leiden eisen voor het onderwijs tot uitdrukking brengen. De met het systeem te verschaffen gegevens zouden bruikbaar moeten zijn voor de studie- en beroepskeuzevoorlichting aan leerlingen en studenten in het voortgezet- en het hoger onderwijs.

In het rapport Naar een informatiesysteem onderwijs-arbeidsmarkt, onderzoekprogramma $1987 / 1988$ (ROA-R-1987/2) is de opzet van het informatiesysteem verder uitgewerkt. Dit rapport kan worden gezien als de eerste versie van een jaarlijks bij te stellen onderzoekprogramma. Het onderzoekprogramma beslaat een elk jaar opschuivende periode van twee jaar, waarbij voor het eerste jaar een definitieve planning wordt gegeven en voor het tweede jaar slechts een voorlopige indicatie. Het onderhavige rapport betreft de programmering voor de periode 1988/1989.

In het programma voor 1987/1988 zijn enkele uitgangspunten genoemd voor de ontwikkeling van het informatiesysteem. Deze zijn nog steeds van kracht. Ze worden onderstaand in verkorte vorm herhaald.

- Het informatiesysteem zal gegevens moeten opleveren ten behoeve van de studie- en beroepskeuzevoorlichting. Deze gegevens zullen overigens tevens van nut kunnen zijn voor de beantwoording van vragen rond de verbetering van de afstemming van de opleidingscapaciteiten op de toekomstige arbeidsmarkt en die met betrekking tot het zodanig structureren van het economisch potentieel, dat meer profijt wordt getrokken van de investeringen in kennis en vaardigheden van de bevolking.

- De te verschaffen informatie zal van kwantitatieve aard moeten zijn. Het gaat dus om het verstrekken van gegevens over de ontwikkeling van de werkgelegenheid en de vervangingsbehoefte in de verschillende 
delen van de arbeidsmarkt, de ontwikkeling van de onderscheiden beroeps- en opleidingscategorieën van de beroepsbevolking, de doorstroming van leerlingen door het onderwijs e.d. Er zullen (vooralsnog) geen kwalitatieve gegevens aan de orde komen, zoals de specifieke inhoud van de beschikbare banen of van het genoten onderwijs.

- Er zal optimaal profijt worden getrokken van reeds beschikbare gegevens en van bestaande kennis.

- Het gaat niet om een eenmalige operatie maar om de ontwikkeling van een duurzaam instrument dat de vereiste (prognose) gegevens met regelmatige frequentie, op basis van actuele inzichten kan verschaffen.

In het eerste onderzoekprogramma is aangegeven dat langs twee lijnen zal worden gewerkt. De eerste lijn betreft het ontwikkelen van een voorlopig informatiesysteem, op basis van direkt beschikbare gegevens en op korte termijn te benutten kennis. De tweede lijn houdt in het ontwikkelen en uitvoeren van een programma van activiteiten, gericht op geleidelijke uitbouw en verbetering van het informatiesysteem. De eerste - voorlopige - versie van het informatiesysteem is inmiddels gereed gekomen en het activiteitenprogramma ter uitbouw en verbetering van dit systeem is thans in uitvoering genomen.

In het vervolgonderzoek zal volgens beide lijnen verder worden gewerkt. Een deel van de activiteiten zal dus bestaan uit het op onderdelen verbeteren en verder uitbouwen van de onderzoeksmethodiek en de databestanden die de basis vormen van het systeem. Een ander deel van de activiteiten omvat het integreren van de nieuwe elementen in het reeds bestaande systeem en het opstellen van nieuwe arbeidsmarktprognoses e.d. Het is op voorhand niet te zeggen welke vorm, wat betreft onderzoeksmethodiek en mate van desaggregatie, het informatiesysteem zal hebben aan het einde van de looptijd van de huidige onderzoeksopdracht van het Ministerie van Onderwijs en Wetenschappen, d.w.z. in 1991. Dit zal deels afhankelijk zijn van de resultaten van de te verrichten deelstudies en deels ook van de ontwikkeling van het beschikbare datamateriaal. In ieder geval zal getracht moeten worden het informatiesysteem de volle breedte van de arbeidsmarkt naar beroepen en 
opleidingen te laten beslaan. Daarbij zal ten aanzien van de beroepen alleen gekeken worden naar de verwachte werkgelegenheidsperspectieven, bij de opleidingen zal daarnaast ook de aanbodkant van de arbeidsmarkt worden geanalyseerd en geprognosticeerd. De opleidingsprognoses zouden tot stand kunnen komen via de onderzoeksbijdragen van het ROA aan de opeenvolgende fasen van het I-SEE project.

Op basis van de huidige CBS-databestanden is het slechts mogelijk werkgelegenheidsprognoses te maken op een relatief hoog aggregatieniveau ${ }^{3}$. Verwacht mag worden dat in de nabije toekomst verder gedesaggregeerde CBS-data met betrekking tot beroepen en academische studierichtingen beschikbaar komen. Aan de oplevering van deze data zijn mogelijk wel omvangrijke kosten verbonden. Het is overigens niet de bedoeling prognoses te gaan maken op deze lage aggregatieniveaus, omdat dit in veel gevallen niet verantwoord is, met name als er geen sprake is van op dat niveau afgebakende deelmarkten. Wel zullen deze gedesaggregeerde data gebruikt worden om te komen tot andere aggregaties, die beter aansluiten bij bestaande arbeidsmarktsegmenten dan de geaggregeerde CBS-data.

Naast deze CBS-data zullen, mede op initiatief van het ROA, additionele databestanden beschikbaar moeten komen op een veel lager aggregatieniveau. Vooralsnog valt niet te zeggen in hoeverre dergelijke informatie reeds voor 1991 in voldoende mate beschikbaar is, om te kunnen worden gebruikt voor het schetsen van de arbeidsmarktperspectieven van beroepen of opleidingen. Op basis van buiten de meerjarige onderzoeksopdracht van het Ministerie van Onderwijs en Wetenschappen gefinancierde studies naar specifieke deelmarkten zouden meer gedesaggregeerde c.q. anders geaggregeerde prognoses kunnen worden opgesteld voor deze specifieke deelmarkten (naar opleiding of beroep). Dergelijk

3Zie ook A. de Grip, J.A.M. Heijke, R.J.P. Dekker, L.F.M. Groot, De arbeidsmarkt naar beroep in 1992 en de positie van academici daarbinnen, ROA-W-1987/1, Maastricht. 
'bottum up' onderzoek zal voor 1991 waarschijnlijk niet over de volle breedte van de arbeidsmarkt kunnen worden verricht, maar zal wel kunnen aangeven welke informatie potentieel door het informatiesysteem zou kunnen worden versterkt. Overigens zal de bijdrage die dergelijke additoneel gefinancierde deelstudies aan het informatiesysteem kunnen leveren in verschillende gevallen slechts indirect of onzeker zijn. Dit is een logisch gevolg van het feit dat zij soms een andere invalshoek zullen hebben dan de rechtstreekse inpassing in het informatiesysteem 4 . Het in dit rapport te ontwikkelen programma zal echter uitsluitend betrekking hebben op de activiteiten die zijn te relateren aan de ontwikkeling van het informatiesysteem. Wel is aan dit programma een overzicht toegevoegd van het buiten de meerjarige opdracht van het Ministerie van Onderwijs en Wetenschappen lopende onderzoek.

Dit nieuwe programmeringsrapport is als volgt opgezet. Eerst wordt in hoofdstuk 2 de positie van het ROA geschetst, zoals deze is gelegen tussen de "leveranciers" van statistische basisgegevens en prognoses en de "afnemers" van de door het ROA te verschaffen informatie over de situatie op de arbeidsmarkt op middellange termijn in relatie tot die in het onderwijs. Vervolgens wordt in hoofdstuk 3 een overzicht gegeven van de eerste versie van het ontwikkelde informatiesysteem onderwijs-arbeidsmarkt. In hoofdstuk 4 wordt tenslotte het activiteitenprogramma voor de periode 1988/1989 aangegeven.

${ }^{4}$ Zie over de voorgeschiedenis van het ROA: Het Researchcentrum voor Onderwijs en Arbeidsmarkt, ROA-R-1986/1, Maastricht. 


\section{DE POSITIE VAN HET ROA}

De positie van het ROA kan worden toegelicht aan de hand van schema 1. Het bovenste deel van het schema heeft betrekking op de gegevens waarop het ROA-informatiesysteem is gebaseerd. Een belangrijke basis wordt gevormd door de statistische gegevens van het CBS over de aantallen werkenden naar beroep, opleiding, leeftijd en arbeidsduur. Met behulp van deze gegevens worden de modellen geschat waarmee de ontwikkelingen op de arbeidsmarkt en die in het onderwijs voor de toekomst worden geprognosticeerd. Uit deze gegevens worden ook de indicatoren berekend die een beeld geven van de werkgelegenheidsrisico's die aan het uitoefenen van de verschillende beroepen en functies zijn verbonden.

Er zal echter worden getracht, naast het CBS, andere bronnen van statistische gegevens aan te boren, die een nauwkeuriger beeld geven van bepaalde onderdelen van de arbeidsmarkt of het onderwijs. Gedacht wordt aan gegevens over de uitstroom uit het onderwijs, met name de bestemming van schoolverlaters op de arbeidsmarkt en aan gegevens over de werkgelegenheid in diverse bedrijfstakken en regio's. Omdat het ROA bij het beschikbaar maken van deze gegevens een actieve rol zou kunnen spelen, zijn de desbetreffende pijlen in het schema in twee richtingen getrokken.

Een belangrijk uitgangspunt voor de prognoses van de ontwikkelingen op de arbeidsmarkt en in het onderwijs wordt gevormd door de toekomstverkenningen van het $C P B$. Het betreft hier met name de middellange-termijnprognoses van de macro-economische ontwikkeling, de werkgelegenheid naar bedrijfstak en de uitstroom uit het onderwijs naar opleidingscategorie. Ook ten aanzien van de prognosegegevens zal worden getracht bronnen aan te boren, die een beter en meer gedifferentieerd beeld geven van bepaalde onderdelen van de arbeidsmarkt of het onderwijs. Er wordt hier met name gedacht aan prognoses op het niveau van het beroepsdomein van bepaalde opleidingscategorieën. Het is denkbaar dat het ROA in de toekomst actief betrokken wordt bij het opstellen van dergelijke meer gedifferentieerde prognoses. 


\section{Schema 1: De positie van het ROA}

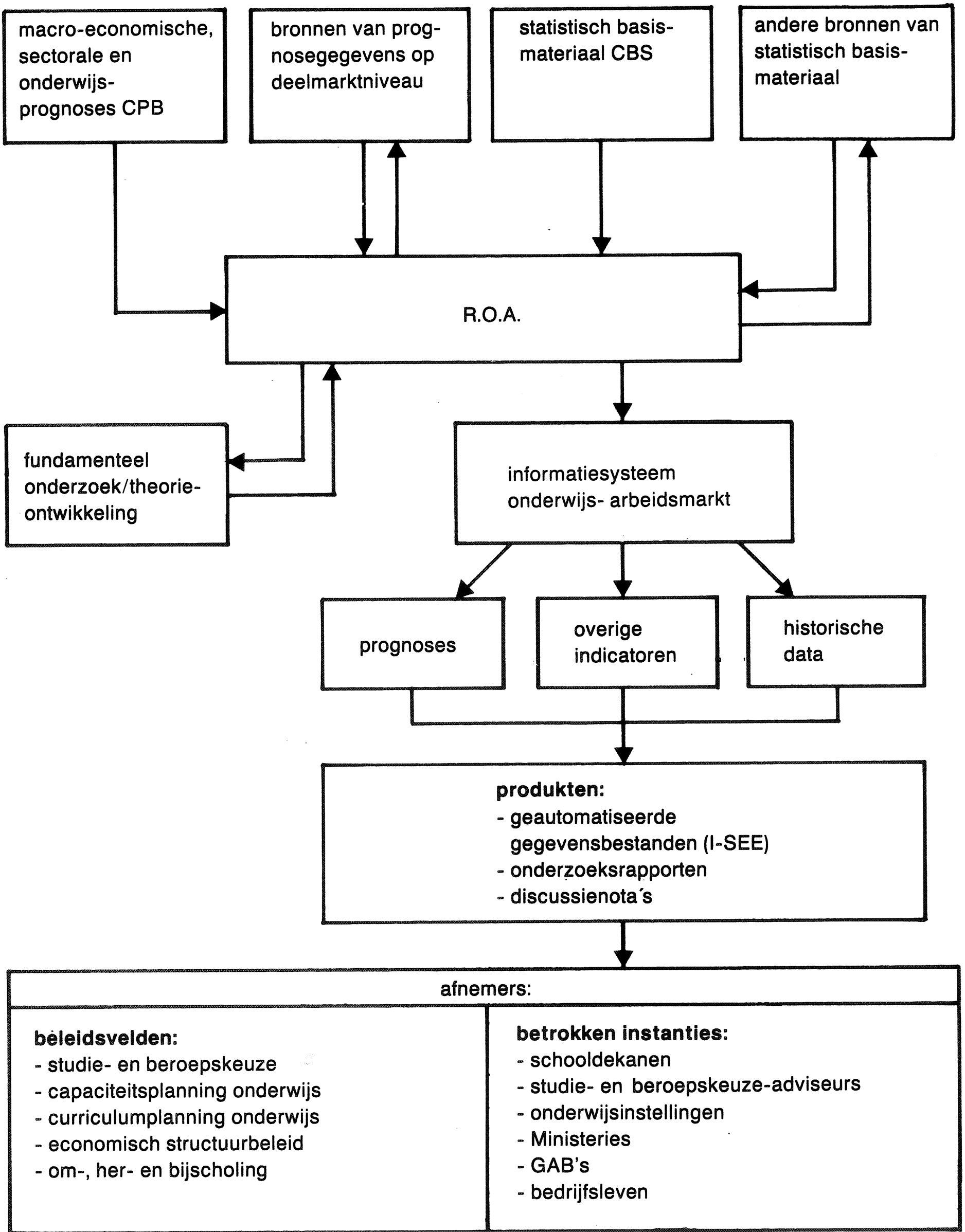


Het is overigens van belang op te merken, dat er momenteel naar gestreefd wordt om de prognose-activiteiten op het terrein van het onderwijs en de arbeidsmarkt zo goed mogelijk te coördineren. Het platform dat hiervoor in het leven is geroepen is de interdepartementale commissie Onderwijs-Arbeidsmarkt Prognoses (OAP). Het ROA participeert in enkele werkgroepen van deze commissie.

Het informatiesysteem onderwijs-arbeidsmarkt wordt ontwikkeld op basis van toegepast wetenschappelijk onderzoek. Door de inpassing van het ROA in de economische faculteit van de Rijksuniversiteit Limburg wordt bevorderd dat zo veel mogelijk profijt kan worden getrokken van onderzoeksresultaten van een meer fundamenteel karakter. Het ROA probeert in aansluiting hierop ook het fundamentele onderzoek binnen de economische faculteit te stimuleren in een richting welke te zijner tijd vruchten zou kunnen afwerpen voor het informatiesysteem onderwijs-arbeidsmarkt.

In het onderste gedeelte van het schema is aangegeven welke informatie het systeem oplevert, in wat voor vorm deze informatie is gegoten en ten behoeve van welke beleidsvelden de informatie zou kunnen worden benut. Er zijn daarbij drie soorten informatie onderscheiden: historische data, prognosegegevens en overige indicatoren met betrekking tot de aansluiting onderwijs-arbeidsmarkt. De verschafte informatie wordt verstrekt zowel in de vorm van een geautomatiseerd gegevensbestand als in de vorm van onderzoeksrapporten en discussienota's. Een geautomatiseerd gegevensbestand zal vooralsnog alleen te raadplegen zijn via het in ontwikkeling zijnde geautomatiseerde school- en beroepskeuzesysteem I-SEE, dat overigens meer modules dan alleen de arbeidsmarktmodule omvat. De uitgebrachte rapporten en nota's zijn daarentegen direkt verkrijgbaar bij het ROA. Voor een volledig overzicht van de tot nu toe verschenen publicaties wordt verwezen naar bijlage 1.

De verschafte informatie richt zich thans primair op de studie- en beroepskeuzevoorlichting. De desbetreffende gegevens bieden echter ook goede aanknopingspunten voor de planning van leerlingencapaciteiten en 
curricula in het onderwijs, het economische structuurbeleid, de omher- en bijscholing van werkenden en werklozen en de personeelsplanning van bedrijven en instellingen. De potentiële afnemers van de informatie worden gevormd door de instanties die op de genoemde beleidsvelden actief zijn. In het schema worden de volgende instanties genoemd: schooldecanen, studie- en beroepskeuze-adviseurs, onderwijsinstellingen, ministeries, arbeidsbureaus en bedrijven. 


\section{HET INFORMATIESYSTEEM ONDERWIJS-ARBEIDSMARKT}

In schema 2 is aangegeven hoe het informatiesysteem onderwijs-arbeidsmarkt er thans uitziet. Het schema vormt een verdere uitwerking en concretisering van het schema "werkgelegenheid informatiesysteem" op bladzijde 18 van het onderzoekprogramma 1987/1988 (ROA-R-1987/2). De belangrijkste verschillen ten opzichte van het vorige schema zijn dat (1) ten aanzien van de werkgelegenheid ook de vervangingsvraag wordt geprognosticeerd,

(2) naast de werkgelegenheid naar beroep ook die naar opleiding is onderscheiden,

(3) een confrontatie plaatsvindt van de vraag naar nieuwkomers met de uitstroom uit het onderwijs en

(4) aanvullende arbeidsmarktindicatoren zijn onderscheiden met betrekking tot de werkgelegenheidsrisico's van bepaalde beroepen en opleidingen.

Deze uitbreiding is mogelijk gemaakt door de aanvullende onderzoeksopdrachten ten behoeve van de ontwikkeling van het geautomatiseerde school- en beroepskeuzesysteem I-SEE.

Het bovenste deel van het schema heeft betrekking op de belangrijkste veronderstellingen die ten grondslag liggen aan de prognoses. Het middendeel geeft de globale structuur van het systeem weer. In het onderste deel van het schema zijn de gegevens genoemd die het informatiesysteem oplevert.

De gemaakte veronderstellingen betreffen de uitgangspunten van de macro-economische en de bedrijfstakprognoses van het Centraal Planbureau $(C P B)$. Verder zijn van belang de door het CPB veronderstelde of geprognostiseerde ontwikkelingen van de arbeidsduur, de mate van deeltijdarbeid, de participatiegraad van de bevolking, de demografische ontwikkeling en de daaruit afgeleide ontwikkeling van de leerlingenstromen door en uit het onderwijs. 


\section{Schema 2:}

Informatiesysteem Onderwijs-Arbeidsmarkt; de Arbeidsmarktperspectieven (I)

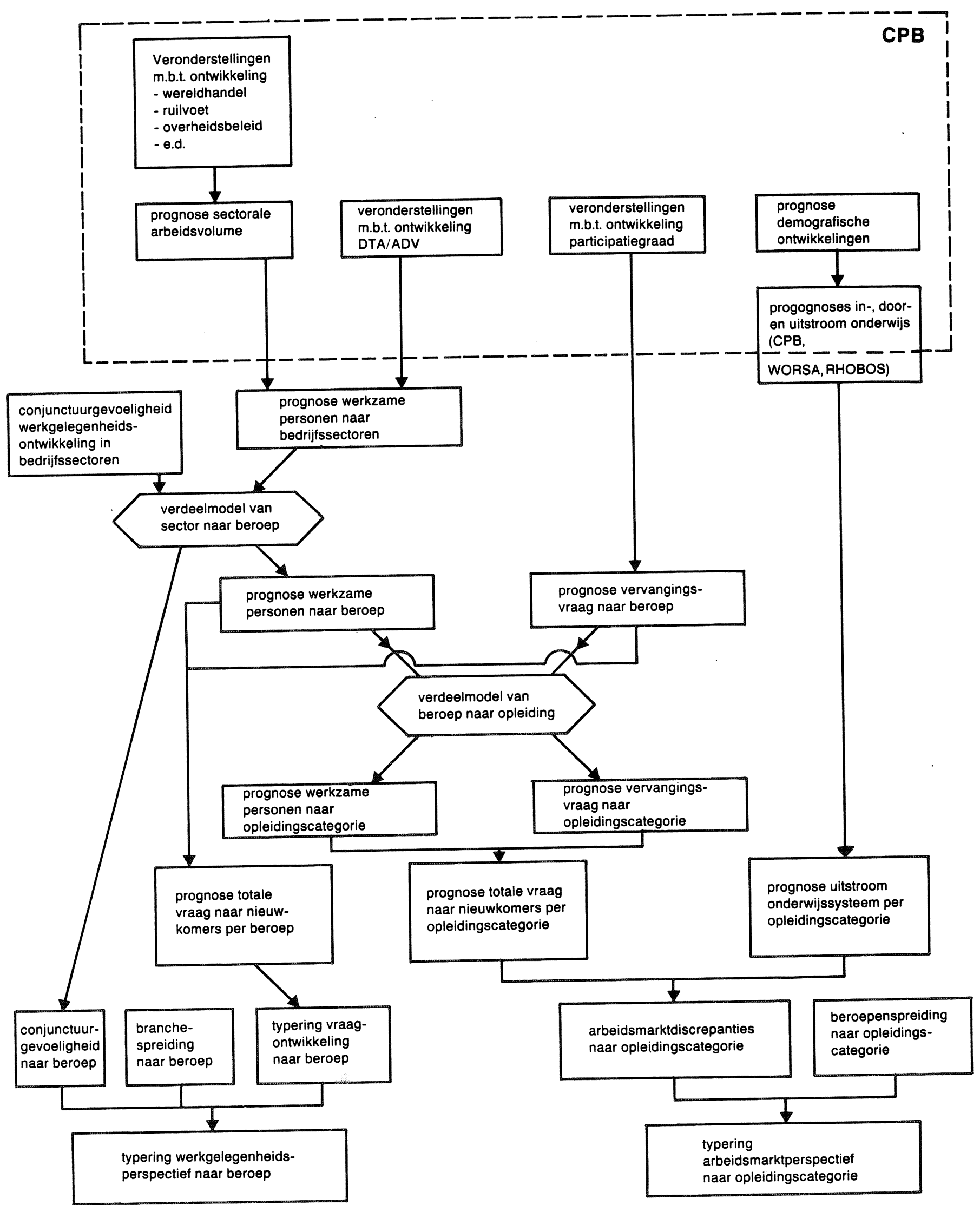


Uit de prognoses van het arbeidsvolume en de arbeidsduur naar bedrijfstak van het CPB wordt de werkgelegenheid in personen naar bedrijfstak afgeleid. Door het toepassen van sectorale beroepenverdeelmodellen op de geprognosticeerde werkgelegenheid naar bedrijfstak, worden prognoses verkregen van het aantal werkzame personen naar beroep. Op basis van onder meer de geprognosticeerde participatiegraad van de verschillende leeftijdscohorten en de leeftijdsstructuur van het aantal werkzame personen naar beroep in het basisjaar van de prognose, wordt vervolgens een schatting gemaakt van de toekomstige vervangingsvraag naar beroep. Dit opgeteld bij de geprognosticeerde mutatie van het aantal werkzame personen naar beroep levert een raming op van de totale vraag naar nieuwkomers per beroep gedurende de prognoseperiode.

In het linker benedendeel van het schema staat aangegeven dat de geprognosticeerde vraagontwikkeling naar beroep, samen met de berekende indicatoren van de conjunctuurgevoeligheid en de branchespreiding van de verschillende beroepen, een typering geven van het werkgelegenheidsperspectief naar beroep.

In het schema is aangegeven dat er bij het opstellen van prognoses -in tegenstelling tot de in het vorige onderzoekprogramma voorgestelde onderzoeksopzet- naast een beroepentraject ook een opleidingentraject wordt gevolgd. Het laatste traject heeft vooralsnog alleen betrekking op het universitaire onderwijs. De reden hiervan is de gevolgde fasering bij het I-SEE project. Andere opleidingscategorieën zullen volgens deze fasering pas later aan de orde komen.

In het midden van het schema wordt weergegeven dat met behulp van verdeelmodellen van beroep naar opleiding, de geprognosticeerde werkgelegenheid en vervangingsvraag naar beroep, vertaald wordt naar respectievelijk de werkgelegenheid en vervangingsvraag naar opleidingscategorie. Door optelling van beide laatste grootheden wordt een prognose verkregen van de totale vraag naar nieuwkomers per opleidingscategorie gedurende de prognoseperiode. 
In het rechter benedendeel van het schema is aangegeven dat de voorspelde totale vraag naar nieuwkomers per opleidingscategorie wordt geconfronteerd met de (extern) geprognosticeerde onderwijsuitstroom naar opleidingscategorie. De hieruit resulterende discrepanties en de berekende indicator van de mate van spreiding van de afgestudeerden in een bepaalde opleidingsrichting over de beroepen, geven een typering van het arbeidsmarktperspectief van de desbetreffende opleidingscategorie.

Bovenstaande beschrijving van het informatiesysteem onderwijs-arbeidsmarkt vormt vanzelfsprekend slechts een globale weergave van het informatiesysteem. Voor een volledig inzicht wordt verwezen naar het desbetreffende werkdocument De arbeidsmarkt naar beroep in 1992 en de positie van academici daarbinnen (ROA-W-1987/1).

De hierboven geschetste opzet van het informatiesysteem moet gezien worden als een eerste versie van het onderwijs-arbeidsmarkt informatiesysteem. Zowel de onderzoeksmethodiek als de mate van desaggratie van de op te leveren gegevens zouden nog op verschillende punten moeten worden verbeterd. Om dit te realiseren is het noodzakelijk deelstudies te verrichten met betrekking tot specifieke probleemvelden. Voor de jaren 1988 en 1989 zijn verschillende van dergelijke deelstudies in het onderzoeksprogramma opgenomen (zie paragraaf 4.3 ) 


\section{HET ONDERZOEKPROGRAMMA}

\subsection{Inleiding}

Het programma bestaat uit twee delen. Deel A heeft betrekking op het onderzoek dat wordt uitgevoerd binnen het kader van de meerjarige onderzoeksopdracht van het Ministerie van Onderwijs en Wetenschappen. Deel $B$ betreft een overzicht van het buiten deze opdracht lopende onderzoek.

Het onderzoekprogramma dekt, zoals gezegd, telkens een jaarlijks opschuivende periode van twee jaar, waarbij het eerste jaar een definitieve planning betreft en het tweede jaar slechts een niet-limitatieve indicatie van het in dat jaar te starten onderzoek. De jaarlijkse bijstelling zal plaatsvinden op basis van de voortgang van het onderzoek en de ontwikkeling van nieuwe plannen. Bij elk project is het jaar aangegeven waarin het volgens planning zal beginnen, alsmede het geschatte tijdstip van afronding.

Het nieuwe programma voor de periode 1988/1989 zal in twee stappen worden behandeld. Eerst wordt ingegaan op de voortgang ten aanzien van het oude programma 1987/1988. Hierbij zal worden aangegeven welke projecten zijn afgesloten, welke nog lopen en met welke projecten nog moet worden begonnen. Daarna worden enkele nieuwe projecten genoemd, die aan het oude programma zullen worden toegevoegd. De tweede stap bij de ontwikkeling van het nieuwe programma wordt afgesloten met een overzicht van het programma voor de periode 1988/1989. 


\subsection{Voortgang van het programma $1987 / 1988$}

De aanvankelijke opzet was om zo snel mogelijk een informatiesysteem onderwijs-arbeidsmarkt te ontwikkelen dat zich zou beperken tot de werkgelegenheid naar beroep. De aanvullende onderzoeksopdracht voor de arbeidsmarktmodule van het geautomatiseerde school- en beroepskeuzesysteem I-SEE maakte het mogelijk om het systeem binnen het beschikbare korte tijdsbestek breder op te zetten. De verbreding hield in dat aan de vraagzijde van de arbeidsmarkt de werkgelegenheid naar universitaire afstudeerrichting en de vervangingsvraag naar zowel beroep als universitaire opleiding werden toegevoegd. De aanbodzijde zou volgens de oorspronkelijke plannen op korte termijn in het geheel niet worden meegenomen. Door de aanvullende opdracht voor I-SEE kon echter een confrontatie worden gemaakt van de werkgelegenheidsprognoses naar universitaire afstudeerrichting met prognoses van de uitstroom van afgestudeerden uit het universitaire onderwijs. Dat alleen universitaire opleidingen zijn onderscheiden, heeft zijn oorzaak in de fasering van het I-SEE project. Het is de bedoeling dat bij dit project eerst het universitaire onderwijs aan de orde komt, vervolgens het hogere beroepsonderwijs tot tenslotte de onderste trede van het voortgezet onderwijs wordt bereikt.

Deze verbreding en tegelijkertijd versnelling van de daadwerkelijke ontwikkeling van het informatiesysteem onderwijs-arbeidsmarkt heeft tot gevolg gehad dat de resultaten van de projecten "afbakening van beroeps- en functiedomeinen" (87/1) en "analyse van het aantal gewerkte uren" (87/2) niet konden worden afgewacht alvorens met de eerste versie van het informatiesysteem prognoses werden opgesteld. Er werd volstaan met een traditionele beroepenindeling volgens de 2-digit-indeling en de omrekening van het arbeidsvolume naar werkzame personen werd op pragmatische wijze opgelost. Het eerst genoemde project "afbakening van beroeps- en functiedomeinen" is inmiddels afgesloten met het werkdocument Clustering occupational classes by educational structure (ROA-W-1987/2E). In dit onderzoek zijn door middel van clusteranalyse beroepsdomeinen gedetermineerd op basis van de mate van overeenstemming van het opleidingsprofiel van beroepen naar opleidings- 
richting en -niveau.

Het onderzoek naar de gewerkte uren - met name de ontwikkeling van de deeltijdarbeid naar bedrijfstak en beroep is hier van belang - zal in 1988 worden afgesloten. De bedoeling van deze studie is te analyseren in hoeverre de ontwikkeling van het aandeel van deeltijdarbeid in de verschillende beroepen sector- of beroepsafhankelijk is. Op basis van deze analyse moet het mogelijk zijn een meer verantwoorde prognose te maken van de relatie tussen het door het CPB geprognosticeerde arbeidsvolume en het aantal werkzame personen.

De resultaten van beide projecten zullen worden gebruikt voor de volgende prognoseronde. Deze zal volgens planning in 1989 plaatsvinden, tenzij een aanvullende onderzoeksopdracht, bijvoorbeeld in het kader van een volgende fase van het I-SEE project, een eerdere prognoseronde noodzakelijk maakt.

De volgende projecten in het programma $1987 / 1988$ betreffen het "schatten van verdeelmodellen" (87/3) en het "opstellen van toekomstprojecties" (87/4). Zoals hierboven reeds is gesteld zijn beide projecten afgesloten met het uitbrengen van het rapport De arbeidsmarktperspectieven van studierichtingen in het wetenschappelijk onderwijs 1992 ,

Arbeidsmarktmodule I-SEE project (ROA-R-1987/3) en het werkdocument De arbeidsmarkt naar beroep in 1992 en de positie van academici daarbinnen (ROA-W-1987/1).

Het project "analyse van werkgelegenheidskarakteristieken" (87/5) heeft geleid tot de ontwikkeling van een tweetal indicatoren die een indruk geven van de werkgelegenheidsrisico's die verbonden zijn aan bepaalde beroepen en opleidingen. De ene indicator betreft een fluctuatie-index en de andere een spreidingsmaatstaf. De resultaten van dit project zijn opgenomen in de laatstgenoemde twee publicaties ( $R-1987 / 3$ en $W-1987 / 1)$.

Met de beide inventarisatieprojecten met betrekking tot "instanties die prognoses opstellen" (87/6) en de "instanties die informatie heb- 
ben over technologische ontwikkelingen en nieuwe organisatiepatronen" (87/7) kon nog niet op systematische wijze een begin worden gemaakt. Wel zijn er in de loop van de werkzaamheden verschillende contacten geweest met dergelijke instanties. Binnenkort zal de onderzoekscapaciteit worden uitgebreid, waardoor deze projecten alsnog kunnen worden gestart.

Als eerste in 1988 te starten project werd genoemd "evaluatie van de eerste prognoses " $(88 / 1)$. Bij nader inzien is dit echter te kort na de opstelling van de eerste prognoses. Het lijkt verstandiger om met een evaluatie van de eerste ROA-prognoses nog enige tijd te wachten tot de eerste resultaten van de enquête beroepsbevolking (EBB) van het CBS beschikbaar zijn en om hierbij ook eerder opgestelde prognoses met betrekking tot de aansluiting onderwijs-arbeidsmarkt (ANTOS, NEI) ${ }^{5}$ te betrekken.

Het project "inventarisatie en exploratie van aanvullende data-bestanden" (88/2) loopt reeds en zal worden voortgezet. De soorten gegevens ten aanzien waarvan activiteiten worden ontplooid zijn:

- de bestemming van verlaters van het onderwijs op de arbeidsmarkt;

- meer gedetailleerde gegevens over functie- en beroepsdomeinen;

- verklarende variabelen voor de beroepenverdeelmodellen.

De "internationale conferentie over de toegepaste prognosemethoden" $(88 / 3)$ staat nog steeds op het programma. In 1988 zullen internationale contacten worden gelegd over het doel, de opzet, de deelname en het tijdstip van deze conferentie.

Ook het onderzoek naar de "opleidingseisen van beroepen en functies" (88/4) zal in 1988 worden gestart. Het gaat in dit project met name om het vinden van een adequate methode voor het beschrijven van substitu-

${ }^{5}$ Naar een informatiesysteem onderwijs-arbeidsmarkt, onderzoekprogramma 1987/1988, ROA-R-1987/2, Maastricht. 
tieprocessen. Daarbij zal gekeken worden naar zowel upgradingprocessen als horizontale en verticale verdringing.

Als laatste project uit het programma 1987/1988 werd genoemd het opzetten van een "plan voor verbetering en verdere uitbouw van het informatiesysteem" (88/5). Het aanduiden van deze activiteit als afzonderlijk project lijkt echter weinig zinvol. Het onderzoeksprogramma zelf is immers als een plan voor uitbreiding en verbetering op te vatten.

Overigens loopt er momenteel nog een project dat kan leiden tot een verbetering van de beroepenverdeelmodellen. De nu toegepaste benadering is theoretisch weinig bevredigend, maar moest om redenen van tijddruk worden gevolgd. In het nog lopende project wordt gezocht naar een meer systematische verklaring van de beroepenstructuur van de sectorale werkgelegenheid. Hiervoor worden beroepenverdeelmodellen opgesteld met meer verklarende variabelen. Deze modellen worden door middel van pooling van tijdreeks- en doorsnedegegevens geschat.

\subsection{Het programma $1988 / 1989$}

Deel A: ontwikkeling van het informatiesysteem onderwijs-arbeidsmarkt

In het programma voor 1988/1989 wordt een nieuwe nummering gevolgd van de geplande onderzoekprojecten met betrekking tot de ontwikkeling van het informatiesysteem onderwijs-arbeidsmarkt (Deel A van het programma). De systematiek in de nummering blijft echter dezelfde. Het eerste nummer geeft dus het jaar aan waarin het project begint; het tweede nummer is een volgnummer. In tegenstelling tot het vorige programma wordt nu tevens het geschatte moment van afronding van de projecten vermeld. In principe zal elk project worden afgesloten met een verslag, veelal in de vorm van een werkdocument. Wel kunnen deze verslagen, als dat doelmatig is, worden gecombineerd in één publicatie, zoals het afgelopen jaar het geval is geweest bij de werknota De arbeidsmarkt naar beroep in 1992 en de positie van academici daarbinnen 
(ROA-W-1987/1). Van de projecten die ook in het oude programma voorkwamen is de tekst in het nieuwe programma in enkele gevallen bijgesteld. Het programmadeel dat betrekking heeft op 1989 heeft zoals reeds opgemerkt een voorlopig karakter en zal begin 1989 worden bijgesteld en aangevuld.

88/1. Schatting en analyse van het aantal gewerkte uren naar sector en beroep. Ontwikkeling van een verklarend model voor het prognosticeren van de arbeidsduur naar (sector en) beroep. Afronding: voorjaar/zomer 1988.

$88 / 2$. Ontwikkeling en schatting van beroepenverdeelmodellen van de werkgelegenheid naar sector. Getracht wordt verklarende variabelen te vinden voor de ontwikkeling van de sectorale beroepenstructuur. Schatting van de modellen zal plaatsvinden door pooling van de tijdreeks- en doorsnedegegevens.

Afronding: zomer 1988.

88/3. Voortzetting van het onderzoek naar indicatoren van bepaalde karakteristieken van de werkgelegenheidsontwikkeling naar beroep en opleiding, bijvoorbeeld ten aanzien van de potentiële beroepsmobiliteit.

Afronding: zomer 1988.

88/4. Het ontwikkelen van een methode voor het beschrijven van substitutieprocessen tussen opleidingscategorieën. Daarbij zal een analyse plaatsvinden van zowel upgradingsprocessen als horizontale en verticale verdringing.

Afronding: voorjaar 1989.

88/5. Het ontwikkelen van een opzet voor een in 1988 of 1989 te houden internationale conferentie van experts over de in de diverse landen toegepaste prognosemethoden op het terrein van de aansluitingsproblematiek onderwijs-arbeidsmarkt. Deze conferentie moet betrekking hebben op zowel de toegepaste methoden als de plannen voor verdere uitbouw en verbetering van deze methoden. Getracht moet worden tot een gezamenlijke publikatie van de resultaten van de conferentie te komen.

Afronding: 1988/1989.

$88 / 6$. Inventarisatie van instanties die prognoses opstellen met be- 
trekking tot delen van het onderwijs en de arbeidsmarkt, alsmede een inventarisatie van instanties die informatie hebben over technologische ontwikkelingen en nieuwe organisatiepatronen en hun implicaties voor de omvang en de beroepen- en opleidingsstructuren van de werkgelegenheid. Nagaan van de mogelijkheden om deze prognoses en informatie te verwerken in het informatiesysteem onderwijs-arbeidsmarkt.

Afronding: najaar 1988.

88/7. Voortzetting van het inventariseren en exploreren van aanvullende of nieuw op te zetten databestanden ten behoeve van de verbetering en verdere uitbouw van het informatiesysteem onderwijsarbeidsmarkt. Met name gaat het hier om:

- de bestemming van schoolverlaters op de arbeidsmarkt;

- meer gedetailleerde gegevens over functie- en beroepsdomeinen;

- verklarende variabelen voor de beroepen- en onderwijsverdeelmodellen;

- werkgelegenheidsgegevens naar opleiding en beroep. Doorlopende activiteit.

88/8. Deelname aan de coördinerende werkzaamheden van de interdepartementale commissie Onderwijs-Arbeidsmarkt Prognoses (commissie OAP).

Doorlopende activiteit.

88/9. Onderzoek onder (potentiële) afnemers naar de wenselijke aard en de geschikte vorm (produkten) van de gegevens uit het informatiesysteem onderwijs-arbeidsmarkt. Het gaat hier met name om het vinden van een doelmatige presentatie van de gegevens uit het informatiesysteem zoals dat in een bepaald stadium is ontwikkeld.

Afronding: winter 1988/1989.

89/1. Inpassing van prognosegegevens uit andere bronnen (zie 88/6) in het informatiesysteem onderwijs-arbeidsmarkt. Vanzelfsprekend zal dit slechts kunnen plaatsvinden voor de beroepen en opleidingscategorieën waarover adequate informatie beschikbaar is. Dit project heeft dan ook een pilot-karakter met als doel inzicht te krijgen in de mogelijkheden die de beschikbaarheid van additionele gegevens biedt voor de verdere uitbouw van het in- 
formatiesysteem.

Afronding: zie 89/4.

89/2. Inpassing aanvullende en nieuwe databestanden in het statistische basisbestand van het ROA.

Doorlopende activiteit.

89/3. Evaluatie van de eerste ROA-prognose alsmede van eerder opgestelde prognoses over de volle breedte van de arbeidsmarkt (ANTOS, NEI).

Afronding: najaar 1989.

89/4. Herschatting van de ontwikkelde modellen en opstelling van nieuwe middellange-termijnprognoses naar beroep voor de periode 1989-1994.

Afronding: winter 1989/1990.

89/5. Voortzetting van de doorlopende activiteiten met betrekking tot de dataverzameling en de commissie OAP.

Dee 1 B: overige onderzoekprojecten

- Het traceren van de directe gevolgen van de technologische veranderingen in het bankwezen voor de werkgelegenheid, de beroepenstructuur en de opleidingsbehoefte. Het onderzoek wordt uitgevoerd in het kader van het OECD/CERI-project "Technological Change and Human Resources in the Service Sector". Het project wordt gezameniijk uitgevoerd door de vakgroepen Algemene Economie en Kwantitatieve Economie en het ROA.

Opdrachtgever: Ministerie van Onderwijs en Wetenschappen. Afronding: najaar 1988.

- Het aanvullen van de arbeidsmarktgegevens van het wetenschappelijk onderwijs ten behoeve van de (definitieve) invulling van de arbeidsmarktmodule van I-SEE.

Opdrachtgever: Ministerie van Sociale Zaken en Werkgelegenheid. Afronding: voorjaar 1988.

- Het onderzoeken van de marktpositie van studierichtingen aan de LTS. Het onderzoek wordt uitgevoerd in de vorm van een stageprogramma bij een LTS. Thans wordt onderzoek gedaan naar de bestemming van de 
schoolverlaters van de LTS op de regionale arbeidsmarkt.

Financiële ondersteuning: COA-Limburg.

Afronding lopende fase: najaar 1988.

- Het onderzoeken van de betekenis van de aard en het tijdpatroon van de beschikbare arbeidsmarktinformatie voor de keuzen binnen het onderwijs en voor de allocatie op en de dynamiek van de arbeidsmarkt. Financiering: AIO-plaats uit facultaire pool. Afronding: zomer 1992. 
BIJLAGE 1

PUBLIKATIES/PUBLICATIONS ROA

\section{Rapporten/Reports:}

ROA-R-1986/1 J.A.M. Heijke, Het Researchcentrum voor Onderwijs en Arbeidsmarkt.

ROA-R-1986/1E J.A.M. Heijke, The Research Centre for Education and Labour Market.

ROA-R-1987/1 A. de Grip, J.A.M. Heijke en L.A. Vos, Inventariserend onderzoek arbeidsmarktmodule I-SEE project.

ROA-R-1987/2 Researchcentrum voor Onderwijs en Arbeidsmarkt, Naar een informatiesysteem onderwijs-arbeidsmarkt, onderzoekprogramma $1987 / 1988$.

ROA-R-1987/3 A. de Grip, J.A.M. Heijke, R.J.P. Dekker, L.F.M. Groot en L.A. Vos, De arbeidsmarktperspectieven van studierichtingen in het wetenschappelijk onderwijs, Arbeidsmarktmodule I-SEE project.

Werkdocumenten/Working papers:

ROA-W-1987/1 A. de Grip, J.A.M. Heijke, R.J.P. Dekker en L.F.M. Groot, De arbeidsmarkt naar beroep in 1992 en de positie van academici daarbinnen.

ROA-W-1987/1E A. de Grip, J.A.M. Heijke, R.J.P. Dekker and L.F.M. Groot, Labour Market Prospects for Occupations and Academic Studies in 1992.

ROA-W-1987/2E A. de Grip, L.F.M. Groot and J.A.M. Heijke, Clustering Occupational Classes by Educational Structure.

Herdrukken/Reprints:

nr. 1 A. de Grip, Causes of Labour Supply and Demand Mismatches in the Dutch Building Trades, in: De Economist jrg. 135, $\mathrm{nr} .2,1987, \mathrm{pp} .182-200$.

$n r \cdot 2$

Hans Heijke, The Labour Market Position of Migrants in Selected European Receiving Countries, in: The Future of Migration, OECD, Paris, 1987, pp. 170-209.

$n r \cdot 3$

J.A.M. Heijke, Internationale migratie en bevolkingsstructuur, in: Demografische veranderingen en economische ontwikkelingen, Preadviezen aan de Koninklijke Vereniging voor de Staathuishoudkunde 1987, H.E. Stenfert Kroese B.V., Leiden/Antwerpen, 1987, pp. 
$125-156$.

$n r \cdot 4$

Andries de Grip, Winnaars en verliezers op de arbeidsmarkt 1981-1985, in: Tijdschrift voor Arbeidsvraagstukken, jrg. 3, nr. 4, 1987, pp. 61-69.

$n r \cdot 5$

J.A.M. Heijke, Arbeidsmarktinformatie voor studie en beroepskeuze, in: Dekanoloog, congresbundel, jrg. 25, $\mathrm{nr} .1,1988$, pp. 20-22 en 13-14.

Overige publicaties medewerkers ROA:

Andries de Grip, Onderwijs en arbeidsmarkt; Scholingsdiscrepanties (proefschrift), VU-uitgeverij, Amsterdam, 1987.

A. de Grip, Werkgroep Functie-ordening van het Nederlands Genootschap voor informatica, Functies in de informatica, typering, plaats, functie-vereisten, loopbaanmogelijkheden (boekbespreking), in: Tijdschrift voor Arbeidsvraagstukken, jrg. 3, nr. 2, 1987, pp. 91-92.

Andries de Grip, Arbeidsmarkt als arena (boekbespreking), in: Intermediair, jrg. 23, nr. 33, 1987, pp. 57-59. 


\section{PERSONELE SAMENSTELLING ROA}

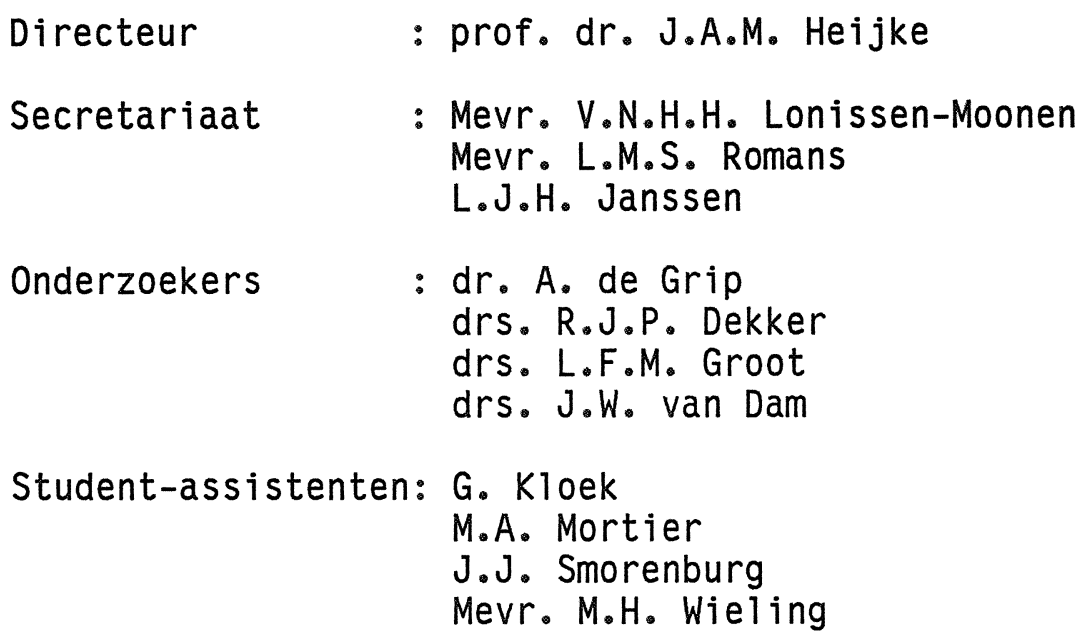

Student-assistenten: G. Kloek

M.A. Mortier

J.J. Smorenburg

Mevr. M.H. Wieling

Adres: Researchcentrum voor Onderwijs en Arbeidsmarkt Tongersestraat 53, kamer 3083

Postbus 616

6200 MD Maastricht

telefoon: $043-888120$ 
VOORLOPIGE BEGROTING PROJECT ONDERWIJS - ARBEIDSMARKT 1988

$\begin{array}{lll}\text { "Tarieven" per maand } & \\ \text { Heijke } 9.500 \times 1,8515^{*} & =f \quad 17.600,-- \\ \text { De Grip } 5.200 & =f \quad 9.700,-- \\ \text { Groot } 3.500 & =f \quad 6.500,-- \\ \text { Dekker } 3.400 & =f \quad 6.300,-- \\ \text { Van Dam } 2.500 & =f \quad 4.700,-- \\ \text { Assistenten } 3.000 & =f \quad 5.600,-- \\ \text { Lonissen } 3.050 & =f \quad 5.700,--\end{array}$

$\begin{array}{lrrr}\text { Heijke } & 8 \text { maanden } & \text { f } 140.800,-- \\ \text { De Grip } & 9 \text { maanden } & \text { f } 87.300,-- \\ \text { Groot } & 6 \text { maanden } & \text { f } & 39.000,-- \\ \text { Dekker } & 12 \text { maanden } & \text { f } & 75.600,-- \\ \text { Van Dam } & 9 \text { maanden } & \text { f } & 42.300,-- \\ \text { Assistenten } & 10 \text { maanden } & \text { f } & 56.000,-- \\ \text { Lonissen } & 9 \text { maanden } & \text { f } & 51.300,--\end{array}$

Overige kosten

f $492.300,--$

$f 57.700,--$

Totaal exclusief BTW

f $550.000,--$

*) $1,8515=1,4 \times 1,15 \times 1,1$ 